\title{
Ageism and Feminism: From "Et Cetera" to Center
}

\author{
TONI CALASANTI, KATHLEEN F. SLEVIN, and NEAL KING
}

Although women's studies scholars and activists do not deny the reality of ageism, they have relegated it to secondary status, neglecting to theorize age relations or place old age at the center of analysis. After explaining what we mean by age relations and their intersections with other inequalities, we discuss the ways in which old people are oppressed, and why age relations represent a political location that needs to be addressed in its own right. We then demonstrate ways in which feminist theories and activism might change if the focus shifted to old people.

Keywords: ageism / age relations / race / sexuality / class

An inadvertent but pernicious ageism burdens much of women's studies scholarship and activism. It stems from failing to study old people on their own terms and from failing to theorize age relations-the system of inequality, based on age, which privileges the not-old at the expense of the old (Calasanti 2003). Some feminists mention age-based oppression but treat it as a given-an "et cetera" on a list of oppressions, as if to indicate that we already know what it is. As a result, feminist work suffers, and we engage in our own oppression. Using scholarship on the body and carework as illustrative, this article explores both the absence of attention to the old and age relations, and how feminist scholarship can be transformed by the presence of such attention.

\section{Neglecting Old Age}

Feminist scholars have given little attention either to old women or to aging (Arber and Ginn 1991), despite Barbara Macdonald's work in the women's movement in the 1980s and her plea that old age be recognized (Macdonald and Rich 1983); despite the increases in absolute and relative numbers of those over age 65, and the skewed sex ratio among old people in the United States; and despite the shifting age ratios in nations worldwide. In her NWSA presidential address at the turn of the century, Berenice Carroll showed where Women's Studies had been and where it will head in the new millennium. She discussed the challenges of women of color and lauds the more recent inclusion of lesbian studies. Nowhere, however, did she mention aging issues (2001). The number of women's studies scholars engaged in work on later life is still so small that those with any interest in aging can count them; the rest (probably the majority) 
may know their names (such as Woodward 1999; Gullette 2004; and Cruikshank 2003) but not their work. The issues go ignored by most scholars, and one must ask why.

\section{The Bias of Middle Age}

Feminists consider age but neither old people nor age relations. They focus on young adult or middle-aged women and on girls. For instance, in the (mostly British) Feminist Perspective Series, the editors argue that the works therein reflect "the current interest in feminist issues and in women's studies in a wide range of fields" (Wallace and Abbott 1999, vii) but exclude aging and old age. Some attend to Sontag's notion of the "double standard of aging," by which women suffer scorn and exclusion as they grow old- "a humiliating process of gradual sexual disqualification" (Sontag 1972, 102). But even studies of women "of a certain age" (Sontag 1972 , 99| focus on middle age-a time when physical markers such as menopause, wrinkles, and the like emerge, and carework for old people begins to occupy women's time. Even though feminists have contributed to the literature on bodies, discussion of old bodies is sorely lacking (Laz 2003). As Twigg notes, a handful of scholars in their 50s or 60s have done important work on age oppression. However, such literature "primarily refers not to deep old age but to the late middle years, roughly equating to fifties to seventies, and to the processes and experiences of aging rather than old age itself" $(2004,62)$. That is, she contends that feminist scholarship on aging bodies has generally not been concerned with the "Fourth Age" - a time qualitatively different from the "Third Age" in that it is marked by serious infirmity. Carework research tends not to examine old women who give or receive care. Brook's scholarship on feminist perspectives on the body-part of the feminist series mentioned earlier-illustrates the neglect of old women by ending its attention to women's bodies at menopause (1999). Old age, as a political location, has been ignored.

Women's studies scholars recently have expressed more concern about aging (perhaps because more feminists are aging); but rarely do they study the old. Not even the few exceptions to this rule examine age relations critically. ${ }^{1}$ The scant scholarship on old age differs markedly from the passionate work on late middle age; it is "Written from the outside, it is about them—the old—not us" (Twigg 2004, 64). Scholars employ others' data to document the disadvantages that women face in old age, such as low income, widowhood, and physical disability. But these accounts of the "problems of old women" (Gibson 1996) do not analyze age relations. For the most part, feminists have not talked to old women to explore their daily experiences; they have not attuned to the advantages old women also might have in relation to old men, such as stronger support networks 
(see Barker, Morrow, and Mitteness 1998). They have not considered the intersections of inequalities with old age such that, for example, old black men are more likely to be poor than are old white women (Calasanti and Slevin 2001).

Feminists exclude old people in their choice of research questions but also in their theoretical approaches when they do study the old. They often write or say "older" rather than "old," to avoid the negativity of the latter. They may see old age as a social construction, and take it as a sign of women's inequality that they are denigrated as "old" before men are; but we do not often question the stigma affixed to old age. We don't ask why it seems denigrating to label someone old. Rather than accept this subordination of old people, we should ask what is so unmentionable about this stage of life. Feminists have analyzed how terms related to girls and women, such as "sissy" and "girly," are used to put men and boys down and reinforce women's inferiority. Yet we have not considered the age relations that use these terms to keep old and young groups in their respective places. For instance, we have been mostly silent about the divisive effects of the so-called "age war" in which the media fuel animosity between generations, especially around matters of employment (Gullette 2004).

Only via a critique of age relations can feminists intervene in the oppression that old people face, especially those marginalized at the intersections of multiple hierarchies. For example, by accepting the cultural dictate to "age successfully" (see Friedan 1993) that underlies the "new gerontology" (Holstein and Minkler 2003), feminists reinforce ageism. Developed by Rowe and Kahn (1998), the notion of successful aging was meant to displace the view of old age as a time of disease and decline with a "vigorous emphasis on the potential for and indeed the likelihood of a healthy and engaged old age" (Holstein and Minkler 2003, 787). Successful aging requires maintenance of the activities popular among the middle-aged privileged with money and leisure time. Thus, staying fit, or at least appearing fit, is highly valued social capital. In this sense, successful aging means not aging, not being "old" or, at the very least, not looking old. The body has become central to identity and to aging, and the maintenance of its youthful appearance has become a lifelong project that requires increasing levels of work.

Many of the age-resisting cultural practices are the purview of women. Successful aging assumes a "feminine" aspect in the ideal that the good, elderly woman be healthy, slim, discreetly sexy, and independent (Ruddick 1999|. Suffice it to say, our standard constructions of old age contain little that is positive. Fear of and disgust with growing old are widespread; people stigmatize it and associate it with personal failure, with "letting yourself go." Furthermore, class, gender, and racial biases embedded in these middle-aged standards emphasize control over and choice about 
aging. We see advertising images of old people playing golf or tennis, traveling, sipping wine in front of sunsets, and strolling (or jogging) on the beaches of upscale resorts. Such pursuits, and the consumption depicted in ads for posh retirement communities, assume a sort of active lifestyle available only to a select group (McHugh 2000): men, whose race and class make them most likely to be able to afford it, and their spouses.

Cruikshank notes the "almost inescapable" judgment that old women's bodies are unattractive; but we know little about how old women endure this rejection (Cruikshank 2003, 147). Thus, though reporting on women who have aged "successfully" (Friedan 1993) might help negate ageist stereotypes of old women as useless or unhappy, it remains ageist in that it reinforces these middle-aged standards. In light of the physical changes that occur as they age, then, many old people must develop strategies to preserve their "youthfulness" so that they will not be seen as old. As a result, old people and their bodies have become subject to a kind of discipline to activity. Those who are chronically impaired, or who prefer to be contemplative are considered to be "problem" old people (Katz 2000; Holstein 1999; Holstein and Minkler 2003). Those who remain active are "not old"; those who are less active are "old" and thus, less valuable.

This study of age relations also complicates theories of gender privilege. For instance, consumer capitalists can profit by the degradation of the status of men as they age. Katz (2001/2002) argues that the advertisements of the anti-aging industry present old men as potentially manly but in need of consumer regimens to remain so. Even old men who are white and rich are also generally retired and weakening, thus losing their institutional grips on the hegemonic ideals of manhood. Once out of the labor market and the realm of those considered sexually desirable by the young, old men find themselves second-class citizens. The men pictured in the anti-aging advertisements drive themselves into expensive and strenuous fun, translating the achievement orientations of the labor market into those of recreational consumption. Banned from the competition for salaries and promotions, they struggle for status by spending the wealth and strength they have to play as young men do, desperate to appear as vigorous as possible.

Proponents of "agelessness" argue that being old is all a social construction (Andrews 1999) - all in how one thinks and acts and ought therefore to be defined away, solving the problem of old age by cultural fiat. To be sure, age categories are subjective, and all stages are constructions. Nevertheless, as Andrews observes, "there is not much serious discussion about eliminating infancy, adolescence, or adulthood from the developmental landscape. It is only old age which comes under the scalpel" (302). Whether our quest is to age successfully or to be ageless, this need to deny old age lies at the heart of ageism. We deny that we are aging, and when forced to confront the process, treat it as ugly and tragic. 
Age categories have real consequences, and bodies-old bodies-matter. They have a material reality along with their social interpretation (Laz 2003). Old people are not, in fact, just like middle-aged persons but only older. They are different. As is the case with other forms of oppression, we must acknowledge and accept these differences, and even see them as valuable. We must distinguish between age resistance and age denial (Twigg 2004, 63); and to do so, we must theorize the age relations that underlie the devaluation of old age.

\section{Age Relations}

Scholars, including gerontologists, have scarcely theorized age relations beyond Laws's (1995) important work on age as one of a complex of social relations. ${ }^{2}$ As a result, our discussion here represents an early stage in this endeavor. Our notion of age relations comprises three dimensions. First, age serves a social organizing principle; second, different age groups gain identities and power in relation to one another; and third, age relations intersect with other power relations. Together, these have consequences for life chances-for people's abilities to enjoy economic security and good health. The focus on age relations enables us to learn more about how all of our positions and experiences rest upon power relations based on age.

The first assertion, that societies are organized on the basis of age, is widely documented by scholars in aging studies. Age is a master status characteristic that defines individuals as well as groups (Hendricks 2003). Societies proscribe appropriate behaviors and obligations based on age. The second and third aspects of age relations speak more directly to issues of power, and how and why such age-based organization matters for life chances. Old age does not just exacerbate other inequalities but is a social location in its own right, conferring a loss of power for all those designated as "old" regardless of their advantages in other hierarchies.

When feminists explore power relations such as those based on gender, we point to systematic differences between women and men (recognizing that other power relations come into play). In theorizing age relations, then, we also posit systematic differences between being, for instance, an old woman and a young woman. This position does not deny the importance of life course and aging processes but instead posits discrimination and exclusion based on age-across lines of such inequalities as race, ethnicity, sexuality, class, or gender. The point at which one becomes "old" varies with these other inequalities. Once reached, old age brings losses of authority and status. Old age is a unique time of life and not simply an additive result of events occurring over the life course. Those who are perceived to be old are marginalized and lose power, they are subjected to violence (such as elder abuse) and to exploitation and cultural imperialism 
(Laws 1995). They suffer inequalities in distributions of authority, status, and money, and these inequalities are seen to be natural, and thus beyond dispute. Below, we briefly discuss how old people experience these inequalities.

\section{Loss of Power}

Old people lose authority and autonomy. For instance, doctors treat old patients differently than younger clients, more often withholding information, services, and treatment of medical problems (Robb, Chen, and Haley 2002). On the one hand, doctors often take the complaints of old people less seriously than younger clients, attributing them to "old age" (Quadagno 1999). On the other hand, old age has been biomedicalized-a process whereby the outcomes of social factors are defined as medical or personal problems to be alleviated by medical intervention. Old people lose their ability to make decisions about their bodies and undergo drug therapies rather than other curative treatments (Wilson 2000; Estes and Binney 1991).

\section{Workplace Issues and Marginalization}

Ageism costs old people in the labor market both status and money. Although the attitudes and beliefs of employers are certainly implicated (see Encel 1999), often ageism is more subtly incorporated into staffing and recruitment policies, career structures, and retirement policies (Bytheway 1995). The inability to earn money in later life means that most old people must rely on others-family members or the state. And when we consider the economic dependence and security of old people, the oppressive nature of age relations becomes apparent. The fiscal policies and welfare retrenchment in many Western countries provide one lens on the discrimination faced by old people as they increasingly face cutbacks. As Wilson notes, "Economic policies are often presented as rational and inevitable but, given the power structure of society, these so-called inevitable choices usually end up protecting younger age groups and resulting in unpleasant outcomes for those in later life (cuts in pensions or charges for health care)" $(2000,9)$. Demographic projections about aging populations are often used to justify such changes, even though relevant evidence is often lacking. Further, neither the public nor decision makers seem willing to consider counterevidence, such as cross-cultural comparisons that reveal little relationship between the percentage of social spending on old persons and their percentage within the overall population (2000). Predictions of dire consequences attendant upon an aging population are similarly unrelated. Indeed, with only 12.4 percent of its population age 65 and over, the United States ranks 37th among countries with at least 10 percent of their population age 65 and over, well below the almost 
19 percent of the top three countries, Italy, Japan, and Greece (Federal Interagency Forum on Aging Related Statistics 2004).

Decreases in income, erosion of pensions, and proposals to "reform" Social Security are not the only ways old people are marginalized when they leave the labor market. Laws suggest that labor market participation shapes identity-such that participation in waged labor "is a crucial element of citizenship, in the definition of social worthiness, and in the development of a subject's self-esteem" $(1995,115)$. In conjunction with the sort of cultural denigration we describe next, the lack of labor market participation encourages young people to see old people as "other" and not fully deserving of citizenship rights (Wilson 2000, 161). Such disenfranchisement may be informal (rather than based in laws), but it is real nonetheless as seen in the previous policy discussion (Laws 1995).

\section{Wealth and Income}

In the contemporary United States, many people believe that many old people hold vast economic resources-an assertion that is certainly counter to claims that old people lose status or money in later life. However, the greatest inequalities in terms of income and wealth exist among old people, such that many are quite poor (Pampel 1998). The vast majority that relies on Social Security to stay above the poverty line offsets the small number of old people with tremendous wealth. In concrete terms, Social Security-with monthly payments that averaged $\$ 1,013$ for men and $\$ 764$ for women in 2003-provides more than half of all income received for two-thirds of old people in the United States; indeed, it amounts to almost half of all income for four-fifths. Even more, it comprises 90 percent or more of all income for a full one-third of elderly people, and 100 percent of all income for more than one-fifth ( 22 percent). Reliance on these payments is high for all but the richest quintile of old people, whose earnings and pensions add more income than does Social Security. Overall economic dependence of old people on this state-administered program is thus quite high, and higher still when we realize that, even with Social Security, about one-fifth of old minority men and more than a fourth of old minority women fall below the age-adjusted poverty line (Social Security Administration 2004; Federal Interagency Forum on Aging Related Statistics 2004).

The poverty line itself provides an example of the differential treatment of old people. The poverty threshold is lower for old people. In 2003, an old person's income had to be below $\$ 8,825$ - compared to $\$ 9,573$ for those under 65-in order to be officially designated "poor" (DeNavas-Walt, Proctor, and Mills 2004). It's worth noting that most of the public is unaware of this. Poverty thresholds are calculated based on estimates of costs for nutritionally adequate diets, and because of slower metabolism, old people 
need fewer calories than younger people. Thus, old people are assumed to need less money than those under 65, despite their high medical expenses. As a result, official statistics greatly underestimate the number of old people who are poor.

\section{Cultural Devaluation}

Finally, old people are subject to a "cultural imperialism" exemplified by "the emphasis on youth and vitality that undermines the positive contributions of older people" (Laws 1995, 113). The reality that being old, in and of itself, is a position of low status is apparent in the burgeoning antiaging industry (including the new field of "longevity medicine"), which is estimated to gross between 27 and 43 billion dollars a year (with the expectation of a rise to $\$ 64$ billion by 2007), depending on how expansive a definition one uses (Mehlman et al. 2004; U.S. Senate, Special Committee on Aging 2001; Dateline NBC, March 6, 2001). Besides ingesting nutritional supplements and testosterone or human growth hormones, increasing numbers of people spend hours at the gym, undergo cosmetic surgery, and use lotions, creams, and hair dyes to erase the physical markers of age. The equation of old age with disease and physical and mental decline is so prevalent that visible signs of aging serve to justify the limitation of the rights and authority of old people. Many view old age as a "natural" part of life with unavoidable decrements-an equation apparent in the medical doctors" treatment of symptoms as "just old age" rather than as signs of illness or injury that merit care. The equation of aging with a natural order justifies ageism.

Old people internalize these notions of old age in early life and carry them as they age. Indeed, they may come to see old age as "a social contagion" that compels them to avoid other old people and to seek the company of those younger than themselves (Slevin 2006/in press). Further, to protest ageism would mean acknowledging one's own old age and stigma (Levy 2001; Minichiello, Browne, and Kendig 2000). As a result, and contrary to common belief that old people vote as a bloc, ageism makes it less likely that old people would band together politically to promote age-based power and rights. ${ }^{3}$

Age relations differ from other power relations in that one's group membership shifts over time. As a result, one can experience both aspects of age relations_-advantage and disadvantage-over the course of a lifetime. Although other social locations can be malleable, such dramatic shifts in status remain uncommon. Few change racial or gender identities, but we all grow old or die first. Intersecting inequalities affect when this (becoming old) occurs, but the fact remains, where individuals stand in relation to old age must change (Calasanti and Slevin 2001). 
Next, we explore how placing old age and age relations at the center of our analysis might transform feminist theories and practices. We look at issues of the body and carework as illustrative of how this deliberate shift of focus creates a more inclusive feminist lens-one that can be applied to multiple issues.

\section{Centering on Old Age: the Challenge to Feminisms}

\section{Aging Bodies}

Because women's studies scholars begin with the experiences of young adults and middle-aged women, much of their argument against cosmetic surgery and the skin-care industry centers on women's relationship to the "male gaze." In this theory, women are styled in visual media to function as erotic spectacle for the pleasure of men (Mulvey 1990, 33). Thus, these critiques concentrate on the male-defined nature of both cosmetic surgery and the skin-care industry. However, when we recognize that an old woman's attractiveness is judged by the disciplining "gaze of youth," then age is revealed as an intersecting axis of inequality (Twigg 2004, 65). Each "gaze" freezes a person as an object defined by subordinate status; and such judgments may be internalized or rejected as foreign by their objects. Yet, the judgments implicit in the male and youthful gazes differ sharply. Twigg describes the power relations between the old care receivers and the younger women who typically bathe them. The naked old people are subjected to the judgmental, always potentially disgusted gaze of youth, indicative of the more subtle stigma attached to old bodies.

Figures of ignorance or scorn, women grow invisible as sexual beings through the aging process-not only in terms of the disappearance of the desirous male gaze, for instance, but also in terms of neglect by younger members of the women's movement and lesbian communities (Holstein 1999; Copper 1986; Macdonald and Rich 1983). Such invisibility calls forth a different set of responses and generates a different form of dependence than those experienced by younger women. In addition, we might ask how putting old women's sexuality at the center of theorizing might change feminist theories. What if we explore the lives of old, heterosexual women who still see themselves as sexual, but feel cast aside rather than objectified? Neither circumstance amounts to privilege, but they are worth exploring separately. Would the expropriation of women's reproductive labor or exploitation of their bodies still seem like defining moments of women's oppression if we took age relations seriously? And how would our judgments be affected by intersecting inequalities? For instance, many black, retired, professional women express an appreciation 
for themselves as sexual beings, in contrast to similar white women who feel less desirous or desired (Slevin and Wingrove 1998; Wingrove and Slevin 1991).

Hurtado argues that white, heterosexual women can gain power by aligning as (potential) mates with white men, a possibility from which women of color are typically excluded (1989). White women thus profit from the subordination of racial and ethnic minority women. Furthering Hurtado's argument about relational privilege, we might point to the ways in which younger women benefit from old women's de/sexualization. That old women are cast aside as sexual partners enhances the abilities of younger women to gain power by partnering with privileged men.

In addition, when we put old women who are lesbian at the center of our analysis, we uncover the ways old age intersects with other social locations in shaping responses to aging and old age. For example, old lesbians may openly reproduce the ageism and age inequality that burdens them in the first place by consciously avoiding other old lesbians and electing to spend time only with younger lesbians (Slevin 2006/in press). Exploring the challenges of being an old lesbian in an ageist and homophobic society enhances a focus on what it means to be a woman in the years when reproduction and heterosexual desirability are no longer privileged.

\section{Carework and Dependence}

Centering on old people also would transform our study of carework. Although many feminists have contributed to this research, they have attended to elder care only in relation to the younger women who must balance it with their paid work (and perhaps other forms of care). Research on and interest in old care receivers or spousal caregivers is nonexistent. Yet, spousal caregivers are both preferred and far more like one another than not, exhibiting few gender differences. Spouses engaged in primary care tend to spend similar amounts of time in carework and perform similar tasks, including personal care (Thompson 2000). ${ }^{4}$ Understanding how and why spouses provide similar care gives us a different lens on carework, such as men's abilities and structural inducements to give care (Risman 1987). Focusing on caregiving relationships among the old also can point to ways in which gender shapes the meanings of the carework experience and how people negotiate identities in its context. For instance, most people believe that women are natural caregivers. As a result, white, middle-class wives who give care may experience more stress than husbands, despite the fact that husbands are often less prepared to engage in these tasks at the outset. At the same time, men may describe their stress in different terms, or keep it to themselves and use alcohol to cope (Calderon and Tennstedt 1998; Calasanti 2006/in press). Such study can reveal problems for caregivers that result from their being men or 
being old, or ways in which frail elders can receive care without feeling dependent (Gibson 1998).

Centering on old careworkers and receivers reveals the power relations embedded in the gaze of youth and the relatively high status given to the care of children. Feminists have long noted that some forms of carework are undervalued, particularly the care of old people (Diamond 1992; Hooyman and Gonyea 1999; Milne and Hatzidimitriadou 2002). This is not simply due to the greater value accorded care performed by men. In part, this is so because care for children is more highly valued. To be sure, the carework that men perform for the young is recognized and often lauded, as we see in the esteem accorded the "stay-at-home father" or fathers who share child care. But the carework that old husbands perform for their wives is virtually invisible-from the public eye and from feminist concern.

These discrepant values also should prompt feminists to rethink issues of dependence. Feminists have exposed the gender and race relations underlying 'dependence' on the welfare state (see Fraser and Gordon 1994; Estes 2004); but age relations also are implicated. For instance, we noted that projections of age-skewed dependency ratios have been used to promote fiscal retrenchment and cutbacks in old-age policies and programs, including the present call for Social Security "reform" (Estes 2004). Yet, when such skewed ratios reflect a large young population, they do not create the same sort of public outcry, despite the reality that young children are more likely to need care than those, say, ages 65-70 (Gee 2000; Calasanti and Slevin 2001).

Those who are economically active-be they family members or the state-hold economic power over those who are not; and the latter are thus dependent upon them (Bytheway 1995). Women largely depend upon men or the state (Gibson 1998), but in old age, men also become dependents of the state, relying upon the redistribution of economic resources through such policies as public pensions. Although many men are cushioned by multiple privileges when old, they still end up in a position regarded as unmanly (Calasanti and Slevin 2001).

Feminists have demonstrated women's productivity by pointing to their engagement in economic but unpaid activities, such as domestic labor. And gerontologists have followed suit in relation to old people. Still, an unchallenged middle-aged bias guides much of this work, so that arguments assume that "productive" is better than "unproductive." As a result, old people feel compelled to stay active in order to be of worth. Making age-blind arguments to demonstrate that old people also are productive, and hence valuable, can result in a sort of tyranny to prove one's productive value, one that is also shaped by gender relations. For example, grandmothers may be pressed into service caring for grandchildren so that their mothers can pursue paid labor or other activities that carry greater 
status. In this way, younger women exploit their elders. Grandmothers may enjoy caring for grandchildren, but the role confines them as well, limiting the freedom old women might otherwise enjoy (Browne 1998; Facio 1996). It reinforces women's status as domestic laborers and servers of others, and it exploits women based on their age in that their unpaid labor benefits other family members (Laws 1995, 116).

The feminist silence on policy issues related to old persons, particularly those disadvantaged by other inequalities, is striking. For instance, little discussion among women's studies scholars ensued before or after Medicare "reform," despite old women's greater reliance on this program and the fact that they are further disadvantaged by its focus on acute illnesses (Hendricks, Hatch, and Cutler 1999). More surprising still, given the women's movement's concern for equal economic opportunities, is the quiet surrounding proposals to "reform" Social Security. The multiple relations of oppression embedded in the debates over privatization and concrete proposals have received attention only from those few feminists within aging studies. It seems likely that age relations not only shape Social Security debates but also the lack of concern of the majority of feminist scholars, intentionally or not. This situation may be analogous to the advantages younger women may have in terms of sexual attractiveness such that they do not question this privilege until it is lost. In like manner, it may be that younger women, who have more job opportunities, pension plans, and the like at their disposal, may well favor privatization at the expense of older women. Thus, the fact that schemes touted by politicians will benefit few younger women does not come to light as such plans are not held up to close scrutiny. Cloaked as the debates are in the sort of "voodoo demographics" (Gee 2000) concerning dependence that we discussed above, much of the public, perhaps including feminist scholars, appear to believe that reform must occur. The ageism and other relations of inequality underlying the privatization movement are palpable. But because feminists focus so closely on earlier ages when they explore dependence, the potentially devastating impact of Social Security reform on disadvantaged groups goes unexplored.

\section{Discussion}

In the 1970s, feminists who argued for the inclusion of women were often ignored or treated with hostility. To overcome the apathy of other scholars and activists, they emphasized gender and relationality. They demonstrated that the inclusion of women would broaden understanding and improve the quality of life for both sexes. Likewise, scholars and activists whose work focuses on aging and ageism have been ignored by the mainstream, including those in Women's Studies. They too must argue 
for inclusion and must demonstrate that old age is a political location, one related to lives of other age groups. But feminists also had other women scholars and advocates with whom they could work, a handful of women in positions of power, and a smattering of pro-feminist men with whom to ally. Where are the old women in Women's Studies, or their advocates? The age relations that push old women from our professions leave us ignorant of their perspectives as we do our collective work. Perhaps because privilege is often invisible, most women's studies scholars and activists have been blind to age relations and deaf to age studies advocates. As with other systems of oppression, people tend not to see the importance or contours of age relations when they are privileged by youth, even if they are disadvantaged in other ways. Are we to wait, then, until we are old before we will take seriously age relations?

To leave age relations unexplored reinforces the inequality old people face, an inequality that shapes other relations of oppression, and one that we reproduce for ourselves. Unlike other hierarchies, in which the privileged rarely become the oppressed, we all face age oppression if we live long enough. We can envision feminists striving to be empowered and to "age successfully" while overlooking the contradictory nature of this endeavor, embedded as it is in the denial of age. Yet, we hope that this specter will prompt women's studies scholars and activists to bring age relations to the center of their analyses.

As feminists and people growing old, we need to be smarter about this. We need to recognize that just as gender, race, class, and sexual orientation serve as organizing principles of power, so too does age. We should no longer assume, rather than theorize, these age relations. We cannot continue to write of gender, or generalize about "women," for instance, as if they were all middle aged or younger any more than we can assume they are all white, middle class, or heterosexual. Further, "adding old people $\mathrm{in}^{\prime \prime}$ to theories developed on the basis of younger groups' experiences is just as fraught as was adding women to male models. It renders old people deviant, telling us little beyond the extent to which they conform to middle-aged norms. We learn little of how their daily lives are shaped by broader social currents as well as their own actions, or how age relations privilege their younger counterparts.

As with other systems of inequality, an exploration of age relations must begin by listening to those disadvantaged by them. However, this process can present complications not encountered with the study of other groups. Because old age is a social location into which people grow, admitting that we are "old" is to admit to loss of privilege and membership in a devalued group - a transition that many people will resist (Minichiello, Browne, and Kendig 2000). In theorizing age relations, then, we would worry less about affixing the chronological age at which middle age or old age occur than about the tensions surrounding the designation of age 
categories, particularly old age. For instance, if an employer or co-workers see a worker as "old," what is the consequence for the individual? How does this vary by gender, race, or other inequalities? Does it matter that women in the workplace are viewed as "old" sooner than men are (Rodeheaver 1990), and if so, how?

Women's studies scholars can explore the process by which old people (and other age groups) "accomplish age" (Laz 2003), an analogous endeavor to doing gender or doing difference (Fenstermaker and West 2002). Of course, our premise is that these are not accomplished alone, but simultaneously. Feminists have given little thought to how age might influence the ways that women and men might do gender. The dubious claim that men and women become more androgynous with age has not been challenged, nor the related claim that they become less sexual. Certainly the way in which 80-year-old women accomplish gender is different from a 20-year-old female; and her race, ethnicity, class, and sexual orientation would shape this process.

Finally, we hope that once women's studies scholars and activists take old age into account, they will work to imbue old age with positive content-a content that reflects the diversity of old people, their lives, and their varied contributions. Rather than having to deny old age, or to strive to look young, old people should be able to be flabby, contemplative, or sexual, or not. In short, the goal of women's studies scholars and activists should be to enhance old people's freedom to choose lifestyles and ways of being old that are suited to them.

Toni Calasanti is Professor of Sociology, and faculty affiliate of both the Center for Gerontology and Women's Studies at Virginia Tech. Previous work includes her book Gender, Social Inequalities, and Aging (with Kathleen Slevin, 2001) and editing a special issue of the Journal of Aging Studies on feminist gerontology (2004). The forthcoming co-edited book (with Kathleen Slevin), Age Matters: Re-aligning Feminist Thinking (2006) discusses why feminists ought to be concerned with age relations, and explores the ways that feminist thinking is transformed when we center on old age. Her present and future research focuses on aging bodies and the anti-aging industry. Send correspondence to 648 McBryde Hall, Department of Sociology, Virginia Tech, Blacksburg,VA 24061; toni@ vt.edu.

Kathleen F. Slevin's scholarship focuses broadly on issues of gender and aging. Her 1998 book (with C. Ray Wingrove), From Stumbling Blocks to Stepping Stones, is an ethnographic exploration of the life experiences of retired professional African American women. She also has published Gender, Social Inequalities, and Aging (with Toni M. Calasanti, 2001) in the Gender Lens series. Her current research is on aging and body 
experiences. Send correspondence to Department of Sociology, College of William and Mary, Williamsburg, VA 23187; keslev@wm.edu.

Neal King is Associate Professor of Interdisciplinary Studies at Virginia Tech. He is the author of Heroes in Hard Times: Cop Action Movies in the U.S. (1999), and co-editor of Reel Knockouts: Violent Women in the Movies (2001). His articles have been published in such journals as Journal of Film and Video, Gender \& Society, Men and Masculinities, and Teaching Sociology. His research interests include social inequality, masculinity, media violence, and violent crime. Send correspondence to Department of Interdisciplinary Studies, Virginia Tech, Blacksburg, VA 24061; nmking@vt.edu.

\section{Notes}

1. This holds regardless of whether the focus is on men or women. Even in those few instances where men's studies scholars adopt a life course view, "the theoretical discourse on masculinities has concentrated on social practices of young to middle-aged men and, by default, marginalized the masculinities of elderly men" (Thompson 1994, 9).

2. For further discussion of some of the issues involved in theorizing age relations, see Calasanti (2003).

3. The Association for the Advancement of Retired People's successful campaign and the subsequent repeal of the Catastrophic Care Act, which would have provided old people with coverage in cases of catastrophic illnesses, is but one example of old people promoting diverse political agendas.

4. This also appears true of non-married partners, though research has rarely focused on this group.

\section{References}

Andrews, M. 1999. "The Seductiveness of Agelessness." Ageing and Society 19:301-18.

Arber, Sara, and Jay Ginn. 1991. Gender and Later Life. Thousand Oaks, CA: Sage Publications.

Barker, Judith C., Joelle Morrow, and Linda S. Mitteness. 1998. "Gender, Informal Social Support Networks, and Elderly Urban African Americans." Journal of Aging Studies 12(2): 199-222.

Brook, Barbara. 1999. Feminist Perspectives on the Body. London: Longman.

Browne, Colette V. 1998. Women, Feminism, and Aging. New York: Springer Publishing Company. 
Bytheway, Bill. 1995. Ageism. Buckingham, UK: Open University Press.

Calasanti, Toni M. 2006/in press. "Gender and Old Age: Lessons from Spousal Caregivers." In Age Matters: Re-Aligning Feminist Thinking. New York: Routledge.

2003. "Theorizing Age Relations." In The Need for Theory: Critical Approaches to Social Gerontology, eds. Simon Biggs, Ariela Lowenstein, and Jon Hendricks, 199-218. New York: Baywood Press.

Calasanti, Toni M., and Kathleen F. Slevin. 2001. Gender, Social Inequalities, and Aging. Walnut Creek, CA: Alta Mira Press.

Calderon, V. and S. L. Tennstedt. 1998. "Ethnic Differences in the Expression of Caregiver Burden: Results of a Qualitative Study." Journal of Gerontological Social Work 30(1-2):162-75.

Carroll, Berenice A. 2001. "Reflections on '2000 Subversions: Women's Studies and the '21st Century."' NWSA Journal 13(1):139-49.

Copper, Baba. 1986. "Voices: On Becoming Old Women." In Women and Aging: An Anthology by Women, eds. Jo Alexander, Debi Berrow, and Lisa Domitrovich, 46-57. Corvallis, OR: Calyx Books.

Cruikshank, Margaret. 2003. Learning to Be Old. New York: Rowman and Littlefield.

Dateline NBC. 2001. 6 March.

DeNavas-Walt, Carmen, Bernadette D. Proctor, and Robert J. Mills. 2004. "Income, Poverty, and Health Insurance Coverage in the United States: 2003." Current Population Reports, P60-226. U.S. Census Bureau. Washington, D.C.: U.S. Government Printing Office.

Diamond, Timothy. 1992. Making Gray Gold: Narratives of Nursing Home Care. Chicago: University of Chicago Press.

Encel, Sol. 1999. "Age Discrimination in Employment in Australia." Ageing International 25: 69-84.

Estes, Carroll L. 2004. "Social Security Privatization and Older Women: A Feminist Political Economy Perspective." Journal of Aging Studies 18(1):9-26.

Estes, Carroll L., and E. A. Binney. 1991. "The Biomedicalization of Aging: Dangers and Dilemmas." In Critical Perspectives on Aging: The Political and Moral Economy of Growing Old, eds. Meredith Minkler and Carroll L. Estes, 117-34. New York: Baywood.

Facio, Elisa. 1996. Understanding Older Chicanas: Sociological and Policy Perspectives. Thousand Oaks, CA: Sage Publications.

Federal Interagency Forum on Aging Related Statistics. 2004. Older Americans 2004: Key Indicators of Well-Being. Washington, D.C.: U.S. Government Printing Office.

Fenstermaker, Sarah, and Candace West, eds. 2002. Doing Gender, Doing Difference: Inequality, Power, and Institutional Change. New York: Routledge.

Fraser, Nancy and Linda Gordon. 1994. "A Genealogy of Dependency: Tracing a Keyword of the U.S. Welfare State." Signs 19:309-36.

Friedan, Betty. 1993. The Fountain of Age. New York: Simon and Schuster.

Gee, E. M. 2000. "Population Politics: Voodoo Demography, Population Aging, and Social Policy." In The Overselling of Population Aging, eds. Ellen Margaret Gee and Gloria Gutman, 5-25. New York: Oxford University Press.

Gibson, Diane. 1998. Aged Care: Old Policies, New Problems. New York: Cambridge University Press. 
1996. "Broken Down by Age and Gender: 'The Problem of Old Women' Redefined." Gender \& Society 10:433-48.

Gullette, Margaret M. 2004. Aged by Culture. Chicago: University of Chicago Press.

Hendricks, Jon. 2003. "Structure and Identity-Mind the Gap: Toward a Personal Resource Model of Successful Aging." In The Need for Theory: Critical Approaches to Social Gerontology, eds. Simon Biggs, Ariela Lowenstein, and Jon Hendricks, 63-87. New York: Baywood Press.

Hendricks, Jon, Laurie Russell Hatch, and Stephen J. Cutler. 1999. "Entitlement, Social Compact, and the Trend toward Retrenchment in U.S. Old-Age Programs." Hallym International Journal of Aging 1(1):14-32.

Holstein, Martha B. 1999. "Women and Productive Aging: Troubling Implications." In Critical Gerontology: Perspectives from Political and Moral Economy, eds. Meredith Minkler and Carroll L. Estes, 359-73. Amityville, NY: Baywood Press.

Holstein, Martha B., and Meredith Minkler. 2003. "Self, Society, and the 'New Gerontology'." The Gerontologist 43(6):787-96.

Hooyman, N. R., and Gonyea, J. G. 1999. "A Feminist Model of Family Care: Practice and Policy Directions." Journal of Women \& Aging 11(2/3):149-69.

Hurtado, Aida. 1989. "Relating to Privilege: Seduction and Rejection in the Subordination of White Women and Women of Color." Signs 14:833-55.

Katz, Stephen. 2000. "Busy Bodies: Activity, Aging, and the Management of Everyday Life." Journal of Aging Studies 14:135-52.

- 2001/2002."Growing Older Without Aging? Positive Aging, Anti-Ageism, and Anti-Aging." Generations 25(4):27-32.

Laws, Glenda. 1995. "Understanding Ageism: Lessons From Feminism and Postmodernism." The Gerontologist 35(1):112-8.

Laz, Cheryl. 2003. "Age Embodied." Journal of Aging Studies 17:503-19.

Levy, Becca R. 2001. "Eradication of Ageism Requires Addressing the Enemy Within." The Gerontologist 41(5):578-9.

Macdonald, Barbara and Cynthia Rich. 1983. Look Me in the Eye: Old Women, Aging and Ageism. San Francisco: Spinsters Ink.

McHugh, K. 2000. "The 'Ageless Self'? Emplacement of Identities in Sun-Belt Retirement Communities." Journal of Aging Studies 14:103-15.

Mehlman, Maxwell J., Robert H. Binstock, Eric T. Juengst, Roseel S. Ponsaran, and Peter J. Whitehouse. 2004. "Anti-Aging Medicine: Can Consumers Be Better Protected?" The Gerontologist 44(3):304-10.

Milne, A., and E. Hatzidimitriadou. 2002. "Isn't He Wonderful? Exploring the Contribution and Conceptualisation of Older Husbands as Carers." Paper presented at the Reconceptualizing Gender and Ageing Conference, University of Surrey, UK, June 2002:25-7.

Minichiello, Victor, Jan Browne, and Hal Kendig. 2000. "Perceptions and Consequences of Ageism: Views of Older People." Ageing and Society 20(3): 253-78.

Mulvey, Laura. 1990. "Visual Pleasure and Narrative Cinema." In Issues in Feminist Film Criticism, ed. Paula Erens, 28-40. Bloomington: Indiana University Press.

Pampel, Fred C. 1998. Aging, Social Inequality, and Public Policy. Thousand Oaks, CA: Pine Forge Press. 
Quadagno, Jill S. 1999. Aging and the Life Course. Boston: McGraw-Hill.

Risman, B. J. 1987. "Intimate Relationships from a Microstructural Perspective:

Men Who Mother." Gender \& Society 1(1):6-32.

Robb, Claire, Hongbin Chen, and William E. Haley. 2002. "Ageism in Mental Health Care: A Critical Review." Journal of Clinical Geropsychology $8(1): 1-12$.

Rodeheaver, Dean. 1990. "Labor Market Progeria." Generations 14(3):53-8.

Rowe, John W., and Robert L. Kahn. 1998. Successful Aging. New York: Pantheon Books.

Ruddick, Sara. 1999. "Virtues and Age." In Mother Time Women, Aging and Ethics, ed. Margaret U. Walker, 45-60. Lanham, MD: Rowman and Littlefield. Slevin, Kathleen F. 2006/in press. "Lesbians Inhabiting Ageing Bodies." In Age Matters: Re-Aligning Feminist Thinking, eds. Toni Calasanti and Kathleen F. Slevin. New York: Routledge.

Slevin, Kathleen F., and C. Ray Wingrove. 1998. From Stumbling Blocks to Stepping Stones: The Life Experiences of Fifty Professional African American Women. New York: New York University Press.

Social Security Administration. 2004. Fast Facts \& Figures about Social Security, 2004. Washington, D.C.: U.S. Government Printing Office.

Sontag, Susan. 1972. "The Double Standard of Aging." In Saturday Review of the Society 55: 29-38. Rpt. in On the Contrary: Essays by Men and Women, eds. Martha Rainbolt and Janet Fleetwood, 1983, 99-112. Albany: State University of New York Press.

Thompson, Edward H., Jr. 2000. "Gendered Caregiving of Husbands and Sons." In Intersections of Aging: Readings in Social Gerontology, eds. Elizabeth W. Markson and Lisa A. Hollis-Sawyer, 333-4. Los Angeles: Roxbury Publishing Company.

- 1994. "Older Men as Invisible in Contemporary Society." In Older Men's Lives, ed. Edward H. Thompson, Jr., 197-219. Thousand Oaks, CA: Sage Publications.

Twigg, Julia. 2004. "The Body, Gender, and Age: Feminist Insights in Social Gerontology." Journal of Aging Studies 18(1):59-73.

U.S. Senate, Special Committee on Aging. 2001. Swindlers, Hucksters and Snake Oil Salesman: Hype and Hope Marketing Anti-Aging Products to Seniors. (Serial No. 107-14). Washington, DC: U.S. Government Printing Office.

Wallace, Claire, and Pamela Abbott. 1999. "Series Editors' Preface." In Feminist Perspectives on the Body, ed. Barbara Brook, vii. London: Longman.

Wilson, Gail. 2000. Understanding Old Age. Thousand Oaks, CA: Sage Publications.

Wingrove, C. Ray, and Kathleen F. Slevin. 1991. "A Sample of Professional and Managerial Women's Success in Work and Retirement." Journal of Women \& Aging 3:95-117.

Woodward, Kathleen, ed. 1999. Figuring Age: Women, Bodies, Generations. Bloomington: Indiana University Press. 